УДК 347.9

\title{
СУБЪЕКТНЫЙ СОСТАВ ИНСТИТУТА ПРЕДСТАВИТЕЛЬСТВА: НОВОВВЕДЕНИЯ И НЕСОВЕРШЕНСТВА
}

\author{
Абрамова Анастасия Викторовна \\ МФЮА
}

Аннотация: В данной статье определены основные несовершенства института представительства с точки зрения субъектов, вовлечённых в данный институт. Также определены нововведения, позволяющие более качественно реализовать функционал данного института. Выделены категории субъектного состава института представительства.

Ключевые слова: институт представительства, субъектная структура института представительства, представитель.

\section{SUBJECT COMPOSITION OF THE INSTITUTE OF REPRESENTATION: INNOVATIONS AND IMPERFECTIONS}

\section{Abramova Anastasia Viktorovna}

Abstract: This article identifies the main imperfections of the institution of representation from the point of view of the subjects involved in this institution. The innovations that allow to implement the functionality of this institute more efficiently are also identified.

Key words: institute of representation, subject structure of the institute of representation, representative.

Целью статьи является предложение путей совершенствования реализации института представительства путём сокращения категорий, формирующих субъектный состав.

Задачами статьи являются:

1. Раскрытие понятия и сути института представительства;

2. Изучение субъектов и структуры правоотношений института представительства;

3. Выделение категорий субъектного Состава института представительства; 
4. Установление зима качественных критериев, определяющих качество реализации функций представителя;

5. Определение нововведений в институте представительства.

В заключении делается вывод о возможностях развития института представительства через усовершенствование субъектного Состава.

Субъекты представительства определяются нормами действующего законодательства:

Представитель;

Представляемый;

Третье лицо.

Представителем является физическое или юридическое лицо, которое по нормам законодательства, представляет интересы представляемого. Представителем может стать только лицо, обладающее полной дееспособностью.

Представляемый - лицо, которое передает представителю часть своих полномочий для осуществления сделок или других действий от своего имени. Согласно закону, представляемый может передать не только полномочия заключать сделки, но и осуществлять другие юридические действия. Необходимостью представительства является неполная дееспособность лица.

Третье лицо - лицо, с которым представитель вступает в отношения по поручению представляемого.

Субъектами представительства являются лица, действующие исключительно по нормам законодательства, в рамках определенных полномочий.

В 2019 году в силу вступили существенные изменения законодательства. Нам в данной статье имеет смысл рассмотреть новшества, касающиеся института представительства.

Федеральный закон от 28 ноября 2018 г. № 451-Ф3 «О внесении изменений в отдельные законодательные акты Российской Федерации» закрепляет требование об обязательном высшем юридическом образовании для представителей сторон по гражданским и арбитражным делам. «О необходимости взаимодействия государства и личности речь идет достаточно давно».

Предусмотрено, что помимо адвокатов ими могут быть только лица, имеющие высшее юридическое образование или ученую степень по юридической специальности. Теперь обязательным является требование о предоставлении в суде документа об образовании: диплома о высшем юридическом образовании либо аттестата о получении ученой степени по 
юридической специальности. Исключение составляют дела, подлежащие рассмотрению мировыми судьями или районными судами.

Требование к наличию высшего юридического образования у представителей, уже сейчас содержится в Кодексе административного судопроизводства, дополнено уточнением - «или ученую степень по юридической специальности».

Рассмотрим более конкретно данные изменения на примере конкретных изменений в законах.

В статье 51 ГПК РФ уточнен перечень лиц, которые не могут быть представителями в суде, за исключением случаев участия их в процессе в качестве представителей соответствующих органов или законных представителей. В новой редакции в перечень включены помощники судей и работники аппарата суда.

Статья 48 ГПК РФ лишилась абзаца 2 пункта 2, в котором говорилось о том, что полномочия органов, ведущих дела организаций, подтверждаются документами, удостоверяющими служебное положение их представителей, а при необходимости учредительными документами.

Статью 49 ГПК РФ дополнили и теперь вместо двух пунктов она содержит в себе четыре, изложенных следующим образом:

1. Представителями в суде могут быть дееспособные лица, полномочия которых на ведение дела надлежащим образом оформлены и подтверждены, за исключением лиц, указанных в статье 51 настоящего Кодекса.

2. Представителями в суде, за исключением дел, рассматриваемых мировыми судьями и районными судами, могут выступать адвокаты и иные оказывающие юридическую помощь лица, имеющие высшее юридическое образование либо ученую степень по юридической специальности.

3. Адвокаты должны представить суду документы, удостоверяющие статус адвоката в соответствии с федеральным законом и их полномочия. Иные оказывающие юридическую помощь лица должны представить суду документы, удостоверяющие их полномочия, а в случаях, предусмотренных частью второй настоящей статьи, также документы о своем высшем юридическом образовании или об ученой степени по юридической специальности.

4. Требования, указанные в части второй настоящей статьи, не распространяются на патентных поверенных по спорам, связанным с правовой охраной результатов интеллектуальной деятельности и средств индивидуализации, арбитражных управляющих при исполнении возложенных 
на них обязанностей в деле о банкротстве, профессиональные союзы, их организации, объединения, представляющие в суде интересы лиц, являющихся членами профессиональных союзов, по спорам, связанным с нарушением или оспариванием прав, свобод и законных интересов в сфере трудовых (служебных) отношений и иных непосредственно связанных с ними отношений, а также на иных лиц, указанных в федеральном законе. Статья 54 ГПК РФ дополнена важным пунктом, согласно которому лицо, участвующее в деле, выдавшее доверенность на ведение дела в суде и впоследствии отменившее ее, обязано незамедлительно известить об отмене суд, рассматривающий дело.

В статье 61 АПК РФ также внесены изменения. Полномочия руководителей организаций, действующих от имени организаций в пределах полномочий, предусмотренных федеральным законом, иным нормативным правовым актом или учредительными документами, подтверждаются представляемыми ими суду документами, удостоверяющими их статус и факт наделения их полномочиями. В предыдущей редакции указывалось на документы, удостоверяющие их служебное положение, а также учредительные и иные документы. В пункте 4 указанной статьи вместо формулировки «другие представители» теперь появились «иные оказывающие юридическую помощь лица».

Пункт 7 КАС РФ также претерпел некоторые изменения. Если раньше он был изложен в такой редакции «от имени общественного объединения или религиозной организации, не являющихся юридическими лицами, имеет право выступать в суде уполномоченный на это участник таких объединения или организации, имеющий высшее юридическое образование, или представитель, которому участники объединения или организации доверили ведение административного дела в суде», то теперь он звучит следующим образом: «от имени общественного или религиозного объединения, не являющегося юридическим лицом, имеет право выступать в суде уполномоченный на это участник такого объединения или представитель, которому участники объединения доверили ведение административного дела в суде».

Пункт 5 статьи 56 КАС РФ дополнена таким же правилом, как и статья 54 ГПК РФ, согласно которому лицо, участвующее в деле, выдавшее доверенность на ведение дела в суде и впоследствии отменившее еe, обязано незамедлительно известить об отмене суд, рассматривающий дело.

Полагаем, важно сказать, что требование обязательного юридического образования затрагивает лишь тех представителей, кто участвует в делах во 
второй и третьей инстанциях. «Целый ряд вопросов реализации образовательных проектов по подготовке юристов для бизнеса в эпоху цифровизации еще не получил должного освещения». Из дел, которые областные и равные им суды рассматривают в первой инстанции часть и так поступает в рамках КАСа, где уже есть требование к представителям о наличии у них высшего юридического образования.

На основании всего вышеизложенного, можно сделать вывод, что законодателем установлены более высокие требования для представителей в области познаний в юриспруденции, что в свою очередь должно привести к повышению профессионального уровня лиц участвующих в процессе и как следствие более грамотного и законного рассмотрения дел. Но видится, что данное требование должно и необходимо вводить ко всем типам представителей во всех звеньях судебной системы.

\section{Список литературы}

1. Викут М.А. Развитие основами гражданского судопроизводства и гражданскими процессуальными кодексами союзных республик института лиц, участвующих в деле. // Проблемы применения Основ гражданского законодательства и Основ гражданского судопроизводства Союза ССР и союзных республик: (Сборник материалов). Саратов, 1971. С. 156-161.

2. Власов А.А. Адвокат как субъект доказывания в гражданском и арбитражном процессе. М.: Юрлитинформ, 2000. С. 240.

3. Ershova I.V., Enkova E.E., Levushkin A.N., Dzhindzholiya K.K. Projectbased approach in training business lawyers for digital economy through the prism of goal setting (Проектный подход при подготовке бизнес-юристов для цифровой экономики через призму целеполагания) // В сборнике: Theory and Practice of Project Management in Education: Horizons and Risks. International Scientific and Practical Conference. SHS Web of Conferences. 2020. Volume 79. C. 1005.

4. Карапетов, А.Г. Сделки, представительство, исковая давность: постатейный комментарий к статьям 153-208 Гражданского кодекса Российской Федерации / А.Г. Карапетов. - М.: М-Логос, 2018. - 1265 с.

5. Левушкин А.Н. Особые экономические зоны в Российской Федерации: проблемы правового регулирования и практика применения // Журнал предпринимательского и корпоративного права. 2016. №3. С. 15. 